\title{
DISTRIBUTION AND STATUS OF HIGHLAND MUSHROOMS: ASTUDY FROM DOLPA, NEPAL
}

\section{S. Devkota}

This study comprises report on mycological exploration in 2006 at the most remote and highland district, Dolpa of Western Nepal. The study area was virgin for mushrooms study. Forty four species were collected, out of which 40 are new to the area. The collected species are parasitic, saprophytic and mycorrhizal associates' in habitat. Locally 22 and five species were used for culinary and medicinal values respectively. Cordyceps sinensis, Morchella conica, M. esculenta, Laetiporus sulphureus, Agaricus bisporus, Termitomyces clypeatus and Cantharellus cibarius are most popular and potential resources from the study sites.

Key words: Caterpillar fungus, Dolpa, macrofungi, morels mushrooms, Nepal

\section{Introduction}

Wild mushrooms or macrofungi have been collected and consumed by people for thousands of years. Out of 69,000 species of fungi described throughout the world, 10,000 species are fleshy macrofungi which are commonly known as mushrooms (Hawksworth, 1991). Wild mushrooms are important Non-Timber Forest Products (NTFPs) from the forests and are being used as food since time immemorial. Collection of wild mushrooms is very common in Nepal and is important for livelihoods in rural areas (Adhikari 2000, Christensen \& Larsen, 2005, Devkota, 2006).

The collection and survey on mycoflora from Nepalese Himalayan belt was at first done by Hooker (1848-54) from Eastern Nepal. The result of his gatherings was published by Berkeley (1854 a, b, c, d). He reported 44 higher fungi in "Indian Fungi" in Hooker's Journal of Botany. Balfour- Browne (1968) published the fungal species collected from eastern and central Nepal. The major studied on wild mushrooms in temperate to alpine regions of Nepal were carried out by Imazeki et al., (1966), Pandey (1976), Singh \& Nisha (1976), Pegler (1977), Waraitch \& Thind (1977), Sacherer (1979), Bhandary (1980), Otani (1982), Thind \& Sharma (1983), Hijortstam \& Ryvarden (1984), Cotter \& Bhandary (1985), Cotter (1987), Adhikari (1988, 1990, 1999, 2000), Bills \& Cotter (1989), Adhikari \& Manandhar (1996), Devkota et al., (2005), Pandey et al., (2006), Rana \& Giri (2006), Devkota, (2006), and Adhikari \& Devkota (2007).

Previously occurrence of Cordyceps sinensis (Sharma, 1974), Lycoperdon perlatum (Lama et al., 2001), Morchella conica and M. esculenta (Ghimire, et al., 2001) were recorded from Dolpa district. 


\section{Materials and Methods}

\section{Site description}

This paper highlights the mushroom diversity in Raha and Majhphal areas of Dolpo district of Nepal. Dolpa covers a total area of $7,932.3 \mathrm{sq} \mathrm{km}$, which is $5.38 \%$ of the total country area. It is in 1225 to $7625 \mathrm{~m}$ in altitude. Maximum temperature recorded is $22^{\circ} \mathrm{C}$ in summer season and $-1^{0} \mathrm{C}$ in winter. Average recorded rainfall is $245 \mathrm{~mm} / \mathrm{year}$ (SNV/WWF, 2001). Shey-Phoksundo National Park (SPNP), the largest national park of Nepal (core park area of $3555 \mathrm{~km} 2$ ) covers a large part of the district. Dolpa has one of the largest stores of high altitude Himalayan medicinal and aromatic plants in Nepal and also a vast body of knowledge related to the management and use of medicinal plants (Ghimire, 2005). Dolpa district has been a famous ground of Cordyceps sinensis and Morchella spp in the country since long time (Subedi, 2001, Devkota, 2006).

On the basis of bioclimatic ground Ghimire (2005) grouped Dolpo region into arid, semi arid humid zone. Main vegetation in study sites are Quercus incana Q. semecarpifolia, Pinus wallichiana, Picea smithiana, Abies spectabilis, Betula utilis, Sorbus cuspidata, Juniperus indica, J. recurva and J. squamata, Rhododendron anthopogon, R. lepidotum, R. nivale, Caragana brevispina and Lonicera spinosa.

\section{Methods}

The mushrooms were photographed in their natural habitat before they were collected. The broken, rotten and insect eaten species were discarded. I made an attempt to collect all the developmental stages of the basidiocarps to have idea of all morphological characters. Field observation formats were prepared to record informations about all the morphological and chemical characters including surrounding ecology of specimens.

The specimens were collected during the year 2006. The specimens were identified examining the microscopic structures and consulting the literatures. The specimens preserved as herbarium were identified with the help of standard literatures (Adhikari, 2000; Bakshi, 1971; Corner, 1950; Fries, 1938; Imazeki, et al., 1988; Pacioni, 1985; Philips, 1981; Purukayastha \& Chandra, 1985; Rinaldi \& Tyndalo, 1972; Svreck, 1975). They were also compared with the specimens at National Herbarium (KATH) and Tribhuvan University Central herbarium (TUCH). The voucher specimens are deposited in Tribhuvan University Central Herbarium (TUCH), Central Department of Botany, Tribhuvan University, Nepal.

\section{Results and Discussion}

\section{Distribution}

A total of 44 macrofungi belonging to 25 families and 37 genera were collected from Raha and Majphal VDCs of Dolpa district. Among the collected species 22 have found with their culinary values and 5 with medicinal values (Table 1). 
Table 1: List of collected mushrooms

\begin{tabular}{|c|c|c|c|c|c|c|c|}
\hline S.N & Col. Date & Locality & $\begin{array}{l}\text { Altitude } \\
\text { (m) }\end{array}$ & Scientific Name & Local Name & Family & Uses \\
\hline 1 & 26.05 .2006 & Raha Gaun & 2845 & Coprinus disseminatus (Pers. : Fr.) Gray & Gobryauu & Coprinaceae & \\
\hline 2 & 26.05 .2006 & Raha Gaun & 2850 & Coprinus comatus (Müll: Fr.) Pers. & Gobryauu & Coprinaceae & \\
\hline 3 & 26.05.2006 & Raha Gaun & 2954 & $\begin{array}{l}\text { Daldinia concentrica (Bull. : Fr.) Ces.\& } \\
\text { De Not. }\end{array}$ & Katheuu & Xylariaceae & \\
\hline 4 & 26.05 .2006 & Raha Gaun & 2954 & Fomitopsis pinicola (Swartz. :Fr.) Karst. & Katheuu & Fomitopsidaceae & \\
\hline 5 & 26.05 .2006 & Raha Gaun & 2954 & Schizophyllum commune Fr. : Fr. & & Schizophyllaceae & \\
\hline 6 & 26.05 .2006 & Raha Gaun & 2954 & Xylaria polymorpha (Pers. : Fr.) Grev. & & Xylariaceae & \\
\hline 7 & 26.05 .2006 & Raha Gaun & 3450 & Coltricia cinnamomea (Jacq. :Fr.) Murr. & & Hymenochaetaceae & \\
\hline 8 & 26.05 .2006 & Raha Gaun & 3145 & Guepinea spathularia (Schw.) Fr. & & Tremellaceae & \\
\hline 9 & 26.05 .2006 & Raha Gaun & 3365 & Trametes versicolor (L. : Fr.) Llyod & & Polyporaceae & \\
\hline 10 & 26.05 .2006 & Raha Gaun & 3305 & Coriolus hirsutus (Fr.) Quel. & & Coriolaceae & \\
\hline 11 & 27.05 .2006 & Raha Gaun & 3055 & Morchella conica Pers. & Mathheura & Pezizaceae & $\begin{array}{l}\mathrm{E} \\
\mathrm{M}\end{array}$ \\
\hline 12 & 27.05 .2006 & Raha Gaun & 3045 & Morchella esculenta L. :Fr. & Mathheura & Pezizaceae & $\begin{array}{l}\mathrm{E}, \\
\mathrm{M}\end{array}$ \\
\hline 13 & 27.05 .2006 & Raha Gaun & 3345 & Pycnoporus cinnabarinus (Jacq. : Fr.) Karst. & & Polyporaceae & \\
\hline 14 & 27.05 .2006 & Raha Gaun & 3035 & Ramaria botrytis (Pers. :Fr.) Ricken & Nangreuauu & Ramariaceae & $\mathrm{E}$ \\
\hline 15 & 03.06 .2006 & Tirtha, Raha & 5050 & Cordyceps sinensis (Berk.) Sacc. & Yarsagumba & Clavicipitaceae & $\begin{array}{l}\mathrm{E} \\
\mathrm{M}\end{array}$ \\
\hline 16 & 05.06 .2006 & $\begin{array}{l}\text { Raha ko Dill, } \\
\text { Raha }\end{array}$ & 4750 & Lycoperdon pyriforme Schaeff. : Pers & Phusseauu & Lycoperdaceae & $\mathrm{M}$ \\
\hline 17 & 09.06 .2006 & Ghatta, Majphal & 2845 & Mycena spp. & & Marasmiaceae & \\
\hline 18 & 09.06 .2006 & Ghatta, Majphal & 3075 & Lactarius volemus (Fr.) Fr. & Sunphureuu & Russulaceae & $\mathrm{E}$ \\
\hline 19 & 09.06 .2006 & Ghatta, Majphal & 3085 & Laccaria proxima (Boud.) Pat. & Thunreuu & Tricholomataceae & $\mathrm{E}$ \\
\hline 20 & 09.06 .2006 & Ghatta, Majphal & 3154 & Hypholoma capnoides Fr. & Nalleuauи & Strophariaceae & $\mathrm{E}$ \\
\hline 21 & 09.06 .2006 & Ghatta, Majphal & 3154 & Lentinus edodes (Berk.) Pegler & & Pleurotaceae & $\mathrm{E}$ \\
\hline 22 & 09.06 .2006 & Ghatta, Majphal & 3155 & Armillaria mellea (Vahl. : Fr.) Kummer. & & Tricholomataceae & $\mathrm{E}$ \\
\hline 23 & 09.06 .2006 & Ghatta, Majphal & 3155 & Heterobasidion annosum (Fr.) Bref. & & Polyporaceae & \\
\hline 24 & 10.06 .2006 & Lahara, Majphal & 2954 & Termitomyces clypeatus (Berk.) Heim. & Nundhukuli & Tricholomataceae & $\mathrm{E}$ \\
\hline 25 & 10.06 .2006 & Lahara, Majphal & 3085 & Plerurots ostreatus(Jacq. : Fr.) Kummer & Kanney & Pleurotaceae & $\mathrm{E}$ \\
\hline 26 & 10.06 .2006 & Lahara, Majphal & 3100 & Clavaria rosea Fr. & & Clavariaceae & \\
\hline 27 & 10.06 .2006 & Lahara, Majphal & 3105 & Clavaria acuta Sch. : Fr. & & Clavariaceae & \\
\hline 28 & 10.06 .2006 & Lahara, Majphal & 3105 & Scleroderma citrinumPers. :Pers. & & Sclerodermataceae & $\mathrm{E}$ \\
\hline 29 & 10.06 .2006 & Lahara, Majphal & 3115 & Clavaria vermicularis Swartz: Fr. & & Clavariaceae & \\
\hline 30 & 10.06 .2006 & Lahara, Majphal & 3115 & Clavulinopsis fusiformis (Sow. : Fr.) Corner. & & Clavariaceae & \\
\hline 31 & 10.06 .2006 & Lahara, Majphal & 3115 & Gleophyllum sepiarium (Schw.) Fr. & & Fomitopsidaceae & \\
\hline 32 & 10.06 .2006 & Lahara, Majphal & 3145 & \begin{tabular}{|l|} 
Russula aurora Krombh. \\
\end{tabular} & Rakteauu & Russulaceae & $\mathrm{E}$ \\
\hline 33 & 10.06 .2006 & Lahara, Majphal & 3155 & Phellinus pini (Fr.) Pilat & & Phellinaceae & \\
\hline 34 & 10.06 .2006 & Lahara, Majphal & 3157 & Helvella crispa (Scop. :Fr.) Fr. & Kaanpureuu & Pezizaceae & $\mathrm{E}$ \\
\hline 35 & 10.06 .2006 & Lahara, Majphal & 3165 & Phellinus igniarius (L. :Fr.) Quel. & & Phellinaceae & \\
\hline 36 & 10.06 .2006 & Lahara, Majphal & 3190 & Russula chloroides (Krombh.) Bres. & & Russulaceae & $\mathrm{E}$ \\
\hline 37 & 10.06 .2006 & Lahara, Majphal & 3208 & Cantharellus cibarius (Fr. : Fr.) Fr. & Sulpeuи & Cantharellaceae & $\mathrm{E}$ \\
\hline 38 & 10.06 .2006 & Lahara, Majphal & 3208 & Laetiporus sulphureus (Fr.) Murr. & Rakteauu & Grifolaceae & $\mathrm{E}$ \\
\hline 39 & 10.06.2006 & Lahara, Majphal & 3305 & $\begin{array}{l}\text { Auricularia auricula - judae (Bull. : Fr.) } \\
\text { Wettst. }\end{array}$ & & Auriculariaceae & $\mathrm{E}$ \\
\hline 40 & 10.06 .2006 & Lahara, Majphal & 3405 & Suillus granulatus (L. :Fr.) Rous. & Laddeauu & Bolytaceae & $\mathrm{E}$ \\
\hline 41 & 10.06 .2006 & Lahara, Majphal & 3450 & Grifola frondasa (Dicks. :Fr.) S.F. Gray & Nangreuauu & Grifolaceae & $\mathrm{E}$ \\
\hline 42 & 10.06 .2006 & Lahara, Majphal & 3550 & Microporus xanthopus (Fr.) Kuntze & & Polyporaceae & \\
\hline 43 & 10.06 .2006 & $\begin{array}{l}\text { Saiquarry, } \\
\text { Majphal }\end{array}$ & 3645 & Agaricus bisporus (Lange) Imbach. & Gobryauu & garicaceae & $\mathrm{E}$ \\
\hline 44 & 18.06 .2006 & Sangtaa, Raha & 3050 & Morcella elata Fr. & Mathheuraa & Pezizaceae & $\begin{array}{l}\mathrm{E} \\
\mathrm{M}\end{array}$ \\
\hline
\end{tabular}

\section{$\mathrm{E}=$ Edible, $\mathrm{M}=$ Medicinal}




\section{History and uses practices}

The exact figure about existing numbers of mushrooms in Dolpa is still not well known, but it is found that Morchella spp (morels) and Cordyceps sinensis (caterpillar fungus) are most demand oriented mushrooms from long years back. Collectors in Raha and Majphal VDCs hunt mushrooms in forested areas and in highland pastures. Preferable mushrooms after caterpillar fungus and morels are Laetiporus sulphureus, Agaricus bisporus, Termitomyces clypeatus and Cantharellus cibarius.

The history of using Morchella spp locally called Mattheuraa or Guchhi chyau is not yet known and elder people are using it since long back from their childhood. According to the respondents the main Morchella occurring locations are Kalika, Rimi, Sharmi, Liku, Tripurakot, Phoksundo, Majphal and Raha. During this research three species of Morchella namely Morchella conica, M. esculenta and M. elata were collected. Locally, Morchella esculenta and $M$. conica are collected in large amount for trading purpose, as they are of high abundance than M. elata.

Sharma, (1974) reported the local belief upon Cordyceps sinensis for its tonic value in Dolpa. But the local people became aware about its market value only after the year 1987 (Devkota, 2006). Indigenous peoples are utilizing this Himalayan treasure for the treatment of different diseases like diarrhea, headache, cough, rheumatism, liver disease, and also as an aphrodisiac and tonic. Internationally it is regarded as Himalayan Viagra (Devkota, 2006, 2007a).

The use of less numbers of fungi for medicinal purposes could be due to the higher availability of medicinal plants in Dolpa. Local people believed that as the price of caterpillar fungus and morel is getting higher and higher, the knowledge about the appreciation of other wild mushrooms is rapidly lost.

\section{High altitude; low poisoning rate}

In present study very few number of instances were recorded where family members were adversely affected due to mushrooms poisoning. However, in the year 2001 , a collector (40 years old) from Rimi VDC died after consumption of poisonous mushrooms. In 1992, four family members of Mr. Manchandra Buda, from Tripurakot VDC, neighboring VDC of Majphal suffered from mushroom poisoning, but no any death incidents occurred.

Locally poisonous mushrooms are called Bhoot chyau and Bhatkhoriyau chyau. Local people of Raha and Majphal used Satuwa (Parish poryphylla) and Timur (Xanthoxylum armatum), to minimize possible poisoning along with vinegar. Addition of vinegar is a worldwide method to minimize and cure mushroom poisoning (Chaube, 1995; Adhikari, 2000; Adhikari et al., 2005; Pandey et al., 2006 and Devkota, 2007b).

\section{Collection and marketing}

In Dolpa, the collection of mushrooms starts from May to August. Males and females and children were actively participating for the collection of Morchella spp. Agaricus bisporus, Termitomyces clypeatus and Cantharellus cibarius. However, to avoid risks of mushroom poisoning, elder people only were found collecting some mushrooms. In study sites morels 
are distributed from the altitude of $3045 \mathrm{~m}-3305 \mathrm{~m}$ in wet and shady coniferous forests, especially on north facing slopes. The main plant associates of morels are Tsuga dumosa, Cupressus torulosa, Pinus wallichina, Picea smithiana, Quercus semicarpifolia, and Abies spectabilis. Ghimire (2005) reported the occurrence of Morchella esculenta in the altitude of 2900 to 3500 in Dolpa. According to the local respondents morels starts to grow in March to May, and occasionally up to August. Morels are collected in wild and are dried by hanging morel garlands in well ventilated part of their houses and sometimes near by hearth. They are not dried in sun as the morel looses its flavor and color.

With the arrival of spring, people from all ethnic and religious background from Dolpa and neighboring districts participate for the collection of Cordyceps sinensis in more than 25 pastures of Dolpa. Normally collection season is from May - July (Devkota, 2008). Both male and female of 7-76 years participate in collection. The common practices of collection are uprooting, picking, gathering, cleaning and drying in shade or in cotton bags. This was done carefully, since breaking off the larva reduces the value.

Morchella spp and Cordyceps sinensis have high demand both in national and international markets. Except these two, mushrooms are used only for immediate consumption. Whereas, Laetiporus sulphureus is sometimes used as a gift item. There is no exact figure available for the collection and export of morels from Nepal. However, Subedi (2001) estimated about $6,000 \mathrm{~kg}$ of dried morels harvested from Jumla, Humla, Mugu and Dolpa districts of Nepal. Study revealed that Morchella conica and Morchella esculenta are common in trade from Dolpa. For the year 2006, the prices for a $\mathrm{kg}$ of dried morels and Cordyceps sinensis in Dolpa were NRs $6000-8000 / \mathrm{Kg}$ and NRs 250,000 - 420,000 / Kg respectively [US \$ $1=$ NRs. 64]. The quality is the main issue for high value of morels and Cordyceps sinensis.

\section{Macrofungi and Sustainability issues}

The practice of intentional fire for the good proliferation of morels and caterpillar fungus is a serious problem in the study area. Though the practice is getting low, but still there are people with strong belief that burning enhance production rate. Mer (1992) reported practice of forest fire in the Indian Himalaya forest to harvest a rich Morchella in the ensuing year. Forest fires in many cases enhance the growth and yield of Morchella for some years (Pilz et al., 2004), but fire in the high altitude Pinus wallichina forests cannot be recommended because it hampers the regeneration pattern (Chirstensen \& Larsen, 2005). The major threats are due to excessive grazing of animals, haphazard collection, over trampling effects, high use of fuel woods and intentional fires (Devkota, 2006, 2008). Fungi represent a major portion of the prevailing biodiversity in forest ecosystems but are overlooked in the management of the forests, despite their evident ecological importance as decomposers, recyclers, mycorrhizal symbionts, and pathogens.

Information on availability of other edible wild mushrooms in the Dolpa is essential. Real and potential collecting areas must be mapped, as well as recording and monitoring the production is necessary. Adhikari (1999) emphasized on the proper collection and use of mushrooms from their surroundings or nature rather than exclusion as these are perishable items. So, domestication of the edible, medicinal and other species is utmost necessary for sustainable socio-economic growth. 


\section{Conclusion}

Dolpa, situated in the west is far from mycological research Nepal and hard to reach due to different topographical settings. This is the first effort to shed light on distribution and status of macrofungi in highlands of Dolpa. As more parts of the Dolpa are still waiting exploration, this knowledge will be helpful for further research and extensions. Commercial harvesting of Cordyceps sinensis and Morchella species in Dolpa is unsustainable unless appropriate and locally sound measures are taken to limit the degradation of suitable habitats. The potential mushroom such as Laetiporus sulphureus could be dried for long term storage. As the area is in remote and scarcity of foods prevails for long term, this kind of procedure may be helpful to overcome malnutrition. So, sustainable management of this species is utmost necessary by conserving old trees of Quercus spp or by the establishment of intensive managed sites.

\section{Acknowledgements}

Rabindra Shahi, Janak Ukheda, Top Bahadur Bohara and local key informants are thanked for their helps and ideas in the field. I am grateful to Dr. M. K. Adhikari, Dr. U. Budathoki, Dr. R.D. Tiwari, Morten Chirstensen and Kamal Acharya for continuous encouragement and suggestion. Head, Central Department of Botany, Tribhuvan University is thankful for providing laboratory facilities. SAFE Concern, Kathmandu is highly thankful for necessary supports to reach in study sites.

\section{References}

Adhikari, M.K. (1988). Polypores (wood rotting fungi) of Nepal. Banko Janakari. 2 (1):9-20.

Adhikari, M.K. (1990). History of mycological explorations in Nepal. Cryptog. Mycol. 11(2): 111-128.

Adhikari, M.K.(1999). Gasteromycetes from Nepal. Nepal's Nature Paradise. Eds. by T.C. Majupuria and R. Kumar. M. Devi, Gwalior, India. 642-654.

Adhikari, M.K. (2000). Mushrooms of Nepal. P.U. Printers, Kathmandu, Nepal.

Adhikari, M.K. and Manandhar, V. (1996). The genus Lactarius in Nepal. Advances in Botany. 21:387-395, India.

Adhikari, M.K and Devkota, S. (2007). The Clavarioid Fungi of Nepal. Plant Resources Bulletin No. 28, Department of Plant Resources Kathmandu, Nepal. 7-22.

Adhikari, M.K., Devkota, S. and Tiwari, R.D. (2005). Ethnomycological Knowledge on Uses of Wild Mushrooms in Western and Central Nepal. Our Nature. (A Biological Journal). 4:13-19

Bakshi, B.K. 1971. Indian Polyporaceae. ICAR , New Delhi.

Balfour-Browne, F.L. (1968). Fungi of recent Nepal expedition. Ibid. 4:99-141.

Berkeley, M.J. (1954a). Decades XLI- XLII. Indian fungi. Hooker's Jour. Bot. Kew. Gard. Misc. Jour. 6: 129-143. b- Decades XLIV - XLVI. Indian fungi. Ibid. 6:161-174. c- Decades XLVIIXLVII. Indian fungi. Ibid. 6: 204-212. d- Decades XLIX - L. Indian fungi. Ibid. 6:225-235. (Reprint 1969, Decades of fungi 1-62, Amsterdam, Asher Co. 280). 
Bhandary, H.R. (1980). Notes on some macrofungi on Nepal. Jour. Nat. Hist. Mus. 4:23-32. Bills, G.F. and Cotter, H.V.T. (1989). Taxonomy and ethnomycology of Lactarius Sec. Dapetes (Russulaceae) in Nepal. Memoirs of New York Botanical Garden. 49:192-197.

Chaube, H.S. (1995). Nutritional and Medicinal Values of Mushrooms. Mushroom production Technologies. University of Agriculture and Technology, India. 1-6

Christensen, M. and Larsen, H. O. (2005). How can Collection of Wild Edible Fungi Contribute to Livelihoods in Rural Areas of Nepal?. Journal of Forest and Livelihood 4(2):50-55.

Corner, E.J.H (1950). A monograph of Clavaria and allied genera. Anno. Bot. Mem. No. 1.

Cotter, H.V.T. (1987). The systematics and ecology of boletes with special reference to the genus Suillus and its ectomycorrhizal relationship in Nepal. Dissertation submitted to the faculty of the Virginia Polytechnic Institute and State University in Partial fulfillment of the requirement for the degree of Ph.D. in Botany, Blacksburge, Virginia, U.S.A. 175p.

Cotter, V.T. and Bhandary, H. R. (1985). Cavimalum indicum (Clavicipitaceae) on Arundinarium in Nepal. Jour. Nat. Hist. Mus. 9:115-120.

Devkota, S. (2006). Yarsagumba [Cordyceps sinensis (Berk) Sacc.]; Traditional Utilization in Dolpa District, Western Nepal. Our Nature. (An International Biological Journal). 4:48-52

Devkota, S. (2007a). Yatra Yarchagunba (= Hunt for Yarchagunba). Kantipur-Koseli (The National Daily) (In Nepali) (14.07. 2007). 15: 146.

Devkota, S. (2007b). Katei Tapailey khana lagnu bhayeko chyau bishalu ta hoena (= Beware with poisonous mushrooms). Manka Kura (Tri monthly magazine) (In Nepali) (Oct-Dec, 2007) $8: 18$

Devkota, S. (2008). Yarsagumba aarthat Himalayan Viagra (=Yarsagumba or Himalayan Viagra). Manka Kura (Tri monthly magazine) (In Nepali) (Jan-March, 2008) 9: 18

Devkota, S., Tiwari, R.D., Manandhar, V.K. and Adhikari, M.K. (2005). Some wild mushrooms collected from Lumle, Kaski, Nepal. In: Plant Resources Bulletin No. 26, Department of Plant Resources Kathmandu, Nepal. 10-15.

Fries, E.M. (1838). Epicrisis Systematis mycologici. Upasala.

Ghimire, S.K. (2005). The Endemic Flora in Dolpo, North-West Nepal: Distribution Patterns, Life Forms, Habitat Specificity and Conservation Status. Botanica Orientalis. 5:30-39.

Ghimire, S. K., Lama, Y. C., Tripathi, G.R., Schmitt, S. and Thomas. Y. A. (2001). Conservation of the Plant Resources, Community Development and Training in Applied Ethnobotany at Shey Phoksundo National Park and its Buffer-zone, Dolpa Third year. WWF Nepal Program Report Series No. 41, WWF Nepal Program, Kathmandu, Nepal.

Hawksworth, D. L. (1991). The fungal dimension of biodiversity: magnitude, significance, and conservation. Mycological Research 95:641- 655.

Hjortstam, K. and Ryvarden, L. (1984). Some new and noteworthy Basidiomycetes (Aphyllophorales) from Nepal. Mycotaxon. 20:133-151. 
Hooker, J.D. (1854). Himalayan Journals. 1-2. J. Murray, London.

Imazeki, R., Kobayashi, Y. and Aoshima, K. (1966). Fungi. The flora of eastern Himalaya. Ed. H. Hara. University of Tokyo, Japan. 611-626.

Imazeki, R., Otani, Y. and Hongo, T. (1988) Coloured Illustration of Fungi of Japan.YAMA-KEI Publishers Co. Ltd. Tokyo, Japan.

Lama, Y.C., Ghimire, S.K. and Thomas, Y. A. (2001). Medicinal Plants of Dolpo: Amchi's Knowledge and Conservation. WWF Nepal and People and Plants Initiative, Kathmandu, Nepal.

Mer, G.S. (1997). Prospects of morel cultivation in the himalaya. Recent reseaches in Ecology, Environment and Pollution Vol. XI: 493-502. Edited by S.C. Sati, J.Saexna and R.C. Dubey. Today and Tomorrow's Printers \& Publishers, New Delhi - 5, India.

Otani, Y. (1982). Cup fungi collected in Nepal. 1. Reports on the Cryptogamic study in Nepal. Ed. Y. Otani, National Science Museum, Tokyo. 75-91.

Pacioni, G. (1985). The Mcdonald's encyclopedia of mushrooms and toadstools. Mcdonald \& Co. Ltd., London.

Pandey, B.D. (1976). Survey, collection, preservation and identification of the mushrooms in Nepal. Nep. Jour. Agri. 6-11: 115-129.

Pandey, N.; Devkota, S.; Christensen, M. and Budathoki, U. (2006). Use of Wild Mushrooms among the Tamangs of Nepal. Nepal Journal of Science and Technology.7:96-104.

Philips, R. 1981. Mushrooms and other Fungi of Great Britain and Europe. Pan Book Ltd. London.

Pilz, D., Weber, N.S., Carter, M.C., Parks, C.G. and Molina, R. (2004). Productivity and Diversity of Morel Mushrooms in Healthy, Burned and Insect-damaged Forests of Northeastern Oregon.Forest Ecology and Management. 198:367-387.

Purukayastha, R.P. and Chandra, A. (1985). Manual of Indian Edible Mushrooms. Jagendra Book Agency, New Delhi, India.

Rana, P. and Giri, A. (2006). Mushroom diversity in the Sagarmatha national park and its buffer zone area. Banko Janakari. 16(2):17-24.

Rinaldi, A. and Tyndalo, V. (1972). The Complete Book of Mushrooms. Crescent Book, New York.

Sacherer, J. (1979). The high altitude Ethnobotany of the Rolwaling Sherpas: a contribution of Nepalese studies. Jour. Res. Cen. Nep. Stud. CNAS 6(2):46-64

Singh, S.C. and Nisha (1974). Exbasidium butleri in Nepal. Ind. Phytopath.27:387-389.

Singh, S.C. and Nisha (1976). A contribution to the parasitic mycoflora of Nepal. Ind. Phytopath. 6:11-14.

Sharma, J.L. (1974). Kautukmaya Dolpo. Sajha Prakashan, Nepal.42. 
SNV/WWF, (2001). Sustainable Tourism Plan for Shey-Phoksundo National Park., Bufferzone and Tourist Access Routes : 2001-2005. Submitted to DNPWC by SNV Nepal/District Partners Programme and WWF Nepal.

Subedi B.P. (2001). Plant Profile: Morel Mushrooms. Himalayan Bioresources. 5. ANSAB, Kathmandu. 12-13

Svreck, M. (1975). A colour guide to Familiar Mushrooms. Octopus Book Company.

Thind, K.S. and Sharma, M.P. (1983). The Nepal Helotiales. Fungi of Indian subcontinent: a collection of papers. Biblio. Mycol. 91:265-279.

Waraitch, K.S. and Thind, K.S. (1977). Fungi of Nepal (Pezizales). Jour Nat. Hist. Mus. 1: 21-34.

\section{Author's Address}

Mr. Shiva Devkota

Central Department of Botany

Tribhuvan University, Kathmandu, Nepal

Email: devkotashiva@yahoo.com 